\title{
PENGATURAN TINDAK PIDANA KORUPSI: ANALISIS DISPARITAS PENANGGULANGAN PENJATUHAN PIDANA DI INDONESIA
}

\author{
I Putu Bayu Pinarta ${ }^{1}$, I Ketut Mertha ${ }^{2}$ \\ ${ }^{1}$ Kejaksaaan Negeri Denpasar, E-mail: bayupinarta@gmail.com \\ 2Fakultas Hukum Universitas Udayana, E-Mail: ketut_mertha@unud.ac.id
}

doi: $\underline{\text { https://doi.org/10.24843/KS.2020.v08.i10.p11 }}$

\begin{abstract}
Abstrak
Tujuan penelitian ini untuk mengetahui faktor-faktor yang menjadi pertimbangan hakim dalam penjatuhan pidana pada kasus tindak pidana korupsi yang menimbulkan disparitas dan konsep ideal agar tidak ada lagi disparitas pidana pada penjatuhan pidana tindak pidana korupsi dikaitkan dengan rasa keadilan masyarakat Indonesia. Metode yang digunakan dalam penelitian ini mempergunakan jenis penelitian hukum yuridis normatif dengan pendekatan perundang-undangan atau statute approach untuk menganalisis. Hasil penelitian ini menunjukkan bahwa faktor-faktor yang menjadi pertimbangan hakim pada kasus tindak pidana korupsi sehingga menimbulkan disparitas putusan pidana meliputi faktor perundang-undangan; pribadi hakim; dan lingkungan yang mencakup faktor politik dan ekonomi dan konsep ideal agar tidak ada lagi disparitas pidana pada penjatuhan pidana tindak pidana korupsi dapat dilakukan dengan cara dibuatnya pedoman pemidanaan; mengkonstruksi kembali (rekonstruksi) pola pemikiran dan perilaku etik hakim; dan upaya untuk memutus perkara yang bebas tendensi.
\end{abstract}

Kata kunci: Hakim; Disparitas Putusan; Korupsi

\begin{abstract}
The objective of this research to reveal factors that are considered by the judge in the criminal punishment on corruption cases which causes disparity and the ideal concept to avoid no more criminal disparity on the criminal punishment of corruption. The method used in this research uses normative juridical legal research with a statutory or statutory approach to analysis. The result of this research indicates that factors that are considered by the judge in the criminal punishment on corruption cases which causes disparity included legislation factors; judge personal factors; and environmental factors which include political and economic factors and the ideal concept so that no criminal disparity on the criminal punishment of corruption can be done by the way made sentencing guidelines that can be used as a reference or guidelines for judges to impose criminal sanctions; constructing (reconstruction) patterns of thought and ethical behavior of judges; and an attempt to break free cases tendencies.
\end{abstract}

\section{Keywords: Judge; Verdict Disparity; Corruption}

\section{Pendahuluan}

Penanggulangan korupsi di Indoensia yang menjadi hambatan dalam penanganan kasus korupsi diantaranya timbulnya disparitas pidana dalam hal pemidanaannya. Permasalahan tersebut sumbernya adalah putusan hakim. Disparitas putusan hakim yang disatu sisi memberikan hukuman yang berat dan disisi lain memberi hukuman yang ringan, mengakibatkan kasus-kasus korupsi sulit untuk diberantas. Kekuasaan Kehakiman sebagai suatu kekuasaan negara yang bebas dan merdeka di satu sisi membawa dampak yang sangat positif terhadap upaya penegakan hukum di 
Indonesia. ${ }^{1}$ Dalam hal ini, hakim menjadi suatu badan yang independent dan putusannya tidak dapat dipengaruhi oleh badan-badan atau kekuasaan lain. Namun demikian, hakim tidak hidup di ruang hampa. Keputusannya meskipun tidak boleh dipengaruhi oleh badan-badan hukum atau kekuasaan lainnya, namun pada kenyataannya putusan hakim sangat dipengaruhi oleh latar belakang pendidikan, nilai moral, kebutuhan ekonomi, lingkungan pergaulan, dan sebagainya. Pengaruh tersebut pada akhirnya dapat mendistorsi keputusan hakim yang bersangkutan. ${ }^{2}$ Oleh karena itu di tengah masyarakat seringkali dikenal istilah putusan hakim berdasarkan "pesanan". Ironisnya "pesanan" ini justru seringkali berasal dari badan hukum lainnya atau dari oknum yang memegang kekuasaan. ${ }^{3}$

Kebebasan hakim dalam menjatuhkan putusannya ternyata juga membawa suatu dampak negatif yaitu munculnya disparitas pidana. Disparitas Pidana (disparity of sentencing) dalam hal ini adalah penerapan pidana yang tidak sama terhadap tindak pidana yang sama (same offence) atau terhadap tindak-tindak pidana yang sifat berbahayanya dapat diperbandingkan (offences of comparable seriousness). 4

Disparitas (disparity: dis-parity) pada dasarnya adalah negasi dari konsep paritas (parity) yang artinya kesetaraan jumlah atau nilai. Dalam konteks pemidanaan paritas artinya adalah kesetaraan hukuman antara kejahatan serupa dalam kondisi serupa. ${ }^{5}$ Dengan demikian disparitas adalah ketidaksetaraan hukuman antara kejahatan yang serupa (same offence) dalam kondisi atau situasi serupa (comparable circumstances). ${ }^{6}$ Konsep disparitas ini sendiri tidak dapat dipisahkan dari prinsip proporsionalitas, prinsip pemidanaan yang diusung oleh Beccaria dimana diharapkan hukuman yang dijatuhkan kepada pelaku kejahatan proporsional dengan kejahatan yang dilakukannya. ${ }^{7}$ Jika konsep paritas dan proporsionalitas ini dilihat dalam satu kesatuan maka, disparitas pemidanaan dapat terjadi juga dalam hal dijatuhinya hukuman yang sama terhadap pelaku yang melakukan kejahatan yang berbeda tingkat kejahatannya.

Adanya perbedaan dalam penjatuhan hukuman atau disparitas pemidanaan menjadi permasalahan ketika terjadi perbedaan hukuman yang dijatuhkan antara perkara yang serupa, sehingga dipandang menimbulkan ketidakadilan serta dapat menimbulkan kecurigaan-kecurigaan di masyarakat. Oleh karenanya, diskursus mengenai disparitas pemidanaan dalam ilmu hukum pidana dan kriminologi tidaklah pernah dimaksudkan untuk menghapuskan perbedaan besaran hukuman terhadap para

\footnotetext{
${ }^{1}$ Muladi. (2011). Independensi Kekuasaan Kehakiman. Semarang: Penerbit Undip, h.17.

2 Kuntoro Mangkusubroto. (2013). Pemberantasan Mafia Hukum. Jakarta: UNDP, h.16-18.

${ }^{3}$ Ibid.

${ }^{4}$ Muladi dan Barda Nawawi Arief. (2012). Dampak Disparitas Pidana dan Usaha Untuk Mengatasinya. Bandung: Alumra, h.26

${ }^{5}$ Allan Manson. (2014). The Law of Sentencing, New York: Irwin Law, h 92-93.

6 Litbang Mahkamah Agung. (2011). Kedudukan dan Relevansi Yurisprudensi untuk Mengurangi Disparitas Putusan Pengadilan. Jakarta: Puslitbang Hukum dan Peradilan Mahkamah

${ }^{7}$ Allan Manson, op.cit. h.82.
} Agung RI, h.6. 
pelaku kejahatan, namun memperkecil rentang perbedaan penjatuhan hukuman tersebut. 8

Di Indonesia, disparitas pemidanaan terkait perkara korupsi bukan hal baru. Boleh jadi, adanya disparitas pemidanaan dalam perkara korupsi merupakan salah satu faktor yang mendorong Undang-Undang Nomor 3 Tahun 1971 tentang Pemberantasan Tindak Pidana Korupsi digantikan dengan Undang-Undang Nomor 31 Tahun 1999 tentang Pemberantasan Tindak Pidana Korupsi (selanjutnya disebut UU No. 31 Tahun 1999). Dimana salah satu perubahan yang terjadi dalam UU No. 31 Tahun 1999 adalah perumusan ancaman hukumannya. Dalam UU No. 31 Tahun 1999, ancaman pidana minimum khusus mulai diatur kembali, serupa dengan model pengaturan dalam Code Penal Napoleon. ${ }^{9}$

Berdasarkan uraian di atas maka dapat dikatakan disparitas pidana dalam tindak pidana korupsi masih terjadi sampai sekarang. Adanya disparitas pidana dalam tindak pidana korupsi ini mengindikasikan bahwa pada penjatuhan putusannya hakim terpengaruh oleh berbagai kepentingan.

Menurut Sudarto, Kitab Undang-Undang Hukum Pidana (selanjutnya disebut KUHP) Indonesia tidak memuat pedoman pemberian pidana straftoemetingsleiddraad yang umum, ialah suatu pedoman yang dibuat oleh pembentuk undang-undang yang memuat asas-asas yang perlu diperhatikan oleh hakim dalam menjatuhkan pidana yang ada hanya aturan pemberian pidana (straftoemetingsleiddraad). ${ }^{10}$ Disparitas pidana juga dapat terjadi pada pemidanaan yang berbeda terhadap dua orang atau lebih terdakwa yang melakukan suatu tindak pidana secara bersama-sama (complicity), namun tanpa pertimbangan yang rasional. Karenanya, sebagaimana pendapat Sudarto, bahwa masalahnya bukan pada menghilangkan disparitas secara mutlak, tetapi bagaimana disparitas tersebut harus reasonable.

Tidak adanya pedoman pemberian pidana yang umum menyebabkan hakim mempunyai kebebasan untuk menentukan jenis pidana, cara pelaksanaan pidana dan tinggi atau rendahnya pidana. Bisa terjadi dalam suatu delik yang sama atau sifat berbahayanya sama tetapi pidananya tidak sama. Namun kebebasan ini tidak berarti bahwa hakimboleh menjatuhkan pidana dengan kehendaknya sendiri tanpa ukuran tertentu.

Berdasarkan uraian di atas maka rumusan masalah dalam penelitian ini sebagai berikut: pertama, faktor-faktor apa saja yang menjadi pertimbangan hakim dalam penjatuhan pidana pada kasus tindak pidana korupsi yang menimbulkan disparitas?; dan Kedua, bagaimana konsep ideal untuk meminimalkan adanya disparitas pidana

8 Denny Agung Prakoso. (2015). Disparitas dalam Penjatuhan Pidana pada Perkara Korupsi Menurut Undang-Undang Nomor 20 Tahun 2001 tentang Korupsi. Jurnal Hukum dan Advokasi, Vol. II, No. 3.

9 Tim peneliti dari Indonesian Corruption Watch (ICW) tidak bermaksud menyatakan bahwa pembuat UU 31 Tahun 1999 yang memberikan ancaman pidana minimum khusus terinspirasi dari Code Penal Napoleon, akan tetapi hanya menunjukan bahwa model pengaturan tersebut telah dikenal lebih dari 1 abad sebelumnya

10 Sudarto. (2006). Kapita Selekta Hukum Pidana. Bandung: Alumni, h.54. 
pada penjatuhan pidana tindak pidana korupsi dikaitkan dengan rasa keadilan masyarakat Indonesia?.

Tujuan penelitian ini untuk menganalisis: pertama, faktor-faktor yang menjadi pertimbangan hakim dalam penjatuhan pidana pada kasus tindak pidana korupsi yang menimbulkan disparitas; dan kedua, konsep ideal untuk meminimalkan adanya disparitas pidana pada penjatuhan pidana tindak pidana korupsi dikaitkan dengan rasa keadilan masyarakat Indonesia.

\section{Metode Penelitian}

Metode penelitian yang digunakan dalam penelitian ini adalah jenis penelitian hukum normatif. Penelitian hukum normatif (normative legal research) merupakan penelitian yang dilakukan dengan cara mengkaji peraturan perundang-undangan yang berlaku atau diterapkan terhadap suatu permasalahan hukum tertentu. Penelitian hukum normatif meneliti hukum dari perspektif internal dengan objek penelitiannya adalah norma hukum. ${ }^{11}$ Penelitian normatif seringkali disebut dengan penelitian doktrinal, yaitu penelitian yang objek kajiannya adalah dokumen peraturan perundangundangan dan bahan pustaka. ${ }^{12}$ Penelitian hukum normatif juga disebut penelitian yang difokuskan untuk mengkaji penerapan kaidah-kaidah atau norma dalam hukum positif. ${ }^{13}$ Menurut I Made Pasek Diantha penelitian hukum normatif berfungsi untuk memberi argumentasi yuridis ketika terjadi kekosongan, kekaburan dan konflik norma. Lebih jauh ini berarti penelitian hukum normatif berperan untuk mempertahankan aspek kritis dari keilmuan hukumnya sebagai ilmu normatif. ${ }^{14}$

\section{Hasil dan Pembahasan}

\subsection{Faktor-faktor yang Menjadi Pertimbangan Hakim dalam Penjatuhan Pidana pada Kasus Tindak Pidana Korupsi yang Menimbulkan Disparita}

Hakim sesuai dengan tugas dan fungsinya serta Hakim dengan segala kewenangan yang dimilikinya merupakan aktor utama penyelenggara kekuasaan kehakiman dan sekaligus sebagai pengawal praktik penegakan hukum dan keadilan. Hakim melalui putusannya, dapat mengubah, mengalihkan, atau bahkan mencabut hak dan kebebasan warga negara, dan semua itu dilakukan dalam rangka menegakkan hukum dan keadilan. ${ }^{15}$ Dalam realitasnya menunjukkan upaya hakim untuk menegakkan hukum dan keadilan melalui putusannya tersebut bukanlah hal yang mudah,16

11 I Made Pasek Diantha. (2017). Metodologi Penelitian Hukum Normatif dalam Justifikasi Teori Hukum. Jakarta: Prenada Media Group, h.12.

12 Peter Mahmud Marzuki. (2011). Penelitian Hukum. Jakarta: Kencana Prenida Media, h.34.

13 Johny Ibrahim. (2012). Teori dan Metodologi Penelitian Hukum Normatif. Malang: Banyumedia, h.295.

14 I Made Pasek Diantha, op.cit. h.12.

15 Rizky Argama. (2014). Pembukaan Pedoman Perilaku Hakim yang Disusun Pada Tahun 2013 oleh Mahkamah Agung Republik Indonesia. Jakarta: Fakultas Hukum UI.

16 Esmi Warassih. (2013). Pemberdayaan Masyarakat dalam Mewujudkan Tujuan Hukum (Proses Penegakan Hukum dan Keadilan). Semarang: Pustaka Undip, h. 10. 
Menurut Fakhrullah berbagai komentar dan pendapat baik yang berbentuk pandangan ataupun penilaian dari berbagai kalangan masyarakat selalu menghiasi media massa yang ada di Indonesia, terkait keputusan Majelis Hakim dalam menjatuhkan pidana terhadap para terdakwa khususnya pada kasus korupsi. ${ }^{17}$

Menurut Magnis Suseno, sikap dan tindakan-tindakan yang harus diambil tidak berdiri di ruang kosong, melainkan harus dipertanggung-jawabkan terhadap nilai-nilai kemanusiaan yang sebenarnya, terhadap tugas dan kewajiban dan terhadap orang lain. Sikap yang diambil secara bebas hanya memadai apabila sesuai dengan tanggung jawab obyektif itu. ${ }^{18}$ Dalam membuat putusan atas perkara yang ditangani harus bersumber pada kemapuan hakim untuk berpikir dan berkehendak secara bebas namun dalam dengan satu catatan bahwa apa yang sudah diputuskan harus dapat dipertanggung-jawabkan kepada masyarakat tanpa mengurangi nilai objektivitasnya.

Berdasarkan uraian di atas, maka dapat dikatakan bahwa faktor-faktor yang mempengaruhi putusan hakim antara lain (1) faktor pada undang-undang itu sendiri; (2) faktor intern; (3) faktor penafsiran; (4) faktor politik; dan (5) faktor sosial. ${ }^{19}$ Berdasarkan hal ini maka faktor undang-undang dapat menjadi pertimbangan hakim pada kasus tindak pidana korupsi sehingga menimbulkan disparitas putusan pidana. Berbagai pengaturan di dalam UU No. 31 Tahun 1999 bukanlah tanpa kekurangan. Duplikasi pengaturan tindak pidana korupsi dan perumusan ancaman pidana menjadi dua persoalan yang mendukung lahirnya disparitas pemidanaandan inkonsistensi putusan dalam tindak pidana korupsi. Untuk menggambarkan masalah-masalah di atas, perlu ditunjukkan potret atas ketentuan korupsi di Indonesia, khususnya pengaturan dalam UU No. 31 Tahun 1999. Pembahasan berikut ini menggambarkan bagian kecil dari masalah dalam UU No. 31 Tahun 1999 yang dirasa memberikan pengaruh besar atas lahirnya disparitas pemidanaan dan inkonsistensi putusan.

Selanjutnya faktor lain yang dapat menimbulkan disparitas putusan pidana adalah faktor keyakinan hakim. Keyakinan ini dipengaruhi faktor kepribadian yang ada di diri hakim seperti misalnya agama, pendidikan, nilai yang dianut dan moralitas serta mentalitas hakim. Selain itu keyakinan hakim juga dipengaruhi oleh lingkungan sosial. ${ }^{20}$ Lingkungan sosial ini mencakup faktor politik, ekonomi, dan seterusnya. Seorang Hakim sangat sulit untuk secara sempurna menutup diri terhadap pengaruh faktor-faktor tersebut.

Dari faktor-faktor tersebut maka dapat dikatakan pada umumnya terjadinya disparitas putusan pidana khususnya dalam tindak pidana korupsi dipengaruhi oleh pola pikir hakim dan sistem nilai yang dianut hakim. Terkait pola pikir hakim, ada dua kecenderungan pola pikir hakim dalam menangani perkara korupsi, yaitu pertama pola pikir hakim yang bercorak positivistik dan kedua pola pikir hakim yang bercorak non-positivistik. Pola pikir hakim dengan corak yang pertama sangat menekankan pada ukuran-ukuran formal teks aturan (aturan sentris) dalam menggali kebenaran

17 Fakhrullah. (2015). Disparitas Penjatuhan Pidana Kurungan Pengganti Pidana Denda Dalam Putusan Kasus Narkotika, Disertasi, Fakultas Hukum Syiah Kuala, Darussalam, Banda Aceh.

18 Franz Magnis Suseno. (2013). Etika Politik: Prinsip-Prinsip Moral Dasar Kenegaraan Modern. Jakarta: Gramedia Pustaka Utama, h. 295

19 Loebby Loqman. (2012). HAM dalam HAP. Jakarta: Datacom, h.100-101.

${ }^{20}$ M. Syamsudin. (2012). Konstruksi Baru Budaya Hukum Hakim Berbasis Hukum Progresif. Jakarta: Kencana Prenada Media Group, h.95-98. 
hukum, sedangkan pola pikir dengan corak yang kedua mengelaborasikan teks aturan hukum dengan konteks sosiolegal ${ }^{21}$ dalam menggali kebenaran hukum. ${ }^{22}$

Faktor selanjutnya yang menimbulkan disparitas putusan pidana adalah tidak adanya pedoman pemindanaan yang dapat digunakan hakim untuk dipertimbangkan dalam menjatuhkan putusannya khususnya pada perkara tindak pidana korupsi. Perundangundangan di Indonesia sampai dengan sekarang ini belum memiliki sistem pemidanaan yang bersifat nasional yang di dalamnya mencakup pola pemidanaan dan pedoman pemidanaan. ${ }^{23}$ Pola pemidanaan, yaitu acuan/pedoman bagi pembuat undang-undang dalam membuat/menyusun peraturan perundang-undangan yang mengandung sanksi pidana. Istilah pola pemidanaan ini sering juga disebut pedoman legislatif atau pedoman formulatif. Sedangkan pedoman pemidanaan adalah pedoman penjatuhan/penerapan pidana untuk hakim (pedoman yudikatif/pedoman aplikatif) Dilihat dari fungsi keberadaannya, maka pola pemidanaan ini seharusnya ada lebih dahulu sebelum perundang-undangan pidana dibuat, bahkan sebelum KUHP nasional dibuat.

\subsection{Konsep Ideal Untuk Meminimalkan Adanya Disparitas Pidana pada Penjatuhan Pidana Tindak Pidana Korupsi Dikaitkan dengan Rasa Keadilan Masyarakat Indonesia}

Setelah teridentifikasi sebagai hal yang menyebabkan terjadinya disparitas pemidanaan yang berpengaruh menghalangi pemberantasan korupsi di Indonesia, selanjuntya adalah mencari alternatif solusi untuk mengurangi disparitas pemidanaan.

a. Perlunya Tujuan dan Pedoman Pemidanaan Dirumuskan/Diformulasikan dalam KUHP

Telah dilakukan berbagai upaya untuk mengatasi perbedaan dalam pemidanaan dan untuk mencapai "keseragaman" dalam pemidanaan (Parity in sentence). Seiring dengan upaya pembaharuan hukum yang menurut Barda Nawawi Arif telah mulai dari "kakek guru hingga ke cucu murid"24, maka masalah pemidanaan juga termasuk dalam pembaharuan dimaksud. Pedoman dan tujuan pemidanaan yang diharapkan/atau yang seyogyanya diformulasikan dalam sistem pemidanaan bukan untuk mengurangi "kebebasan Hakim" seperti yang termaktub dalam Pasal 4 (3) Undang-Undang Nomor 14 Tahun 1970 tentang Ketentuan-Ketentuan Pokok Kekuasaan Kehakiman, melainkan sebagai bentuk tanggung jawab Hakim atas pidana yang dijatuhkan telah sesuai, sepadan dan tepat untuk si pelaku.

${ }^{21}$ Baca Sulistyowati Irianto dan Shidarta. (2012). Metode Penelitian Hukum Konstelasi dan Refleksi. Jakarta: Yayasan Obor Indonesia, h.173-175; Werner Menski. (2013). Comparative Law in a Global Context, The Legal Systems of Asia and Africa. Second Edition. New York: Cambridge University Press, h.161-162.

${ }^{22}$ M. Syamsudin. (2011). Pemaknaan Hakim tentang Korupsi dan Implikasinya terhadap Putusan: Studi Perspektif Hermeneutika Hukum. Jurnal Mimbar Hukum FH UGM, Vol.22, No.4, h.510. Bandingkan dengan Al. Wisnubroto. (2013). Upaya Mengembalikan Kemandirian Hakim Melalui Pemahaman Realitas Sosialnya. Jurnal Hukum Pro Justitia, Vol.XX, No.1, h. 9-23.

${ }^{23}$ Yohanes Suhardin. (2018). Paradigma Rule Breaking dalam Penegakan Hukum yang Berkeadilan. Jurnal Hukum Pro Justitia, Vol. 26, No. 3.

24 Barda Nawawi Arief. (2011). Pembaharuan Hukum Pidana dalam Perspektif Kajian Perbandingan. Bandung: Citra Aditya Bakti, h. 2 
Adanya pedoman dan tujuan pemidanaan "sama sekali" bukan menghilangkan kemandirian dan kebebasan Hakim, melainkan memberi dasar filosofis atas pidana yang dijatuhkan dan juga memberikan perlindungan hakim dari ketersesatan akibat prinsip kebebasan.Pedoman dan tujuan pemidanaan di samping untuk memberi arah Hakim dalam penjatuhan pidana juga dalam rangka menjaga keseimbangan dengan kepentingan yang harus dilindungi dalam Hukum Pidana juga dalam rangka menjaga keseimbangan tiga kepentingan yang harus dilindungi dalam hukum pidana yaitu: kepentingan negara, pelaku tindak pidana dan korban. Tujuan dan pedoman dirumuskan terkandung maksud untuk memberi keyakinan pada Hakim atas pidana yang dijatuhkan telah sesuai dengan perbuatan dan karakter pembuat tindak pidana dan juga untuk membantu Hakim dalam memahami makna dari keputusannya apa yang hendak dicapai dengan pidana yang dijatuhkan.

b. Mengkonstruksi Kembali (Rekonstruksi) Pola Pemikiran dan Perilaku Etik Hakim Rekonstruksi dimaknai sebagai proses membangun kembali atau menciptakan kembali atau melakukan pengorganisasian kembali atas sesuatu. ${ }^{25}$ Sesuatu yang dimaksudkan adalah pola pikir hakim. Jadi, rekonstruksi pola pikir hakim berbasis hukum progresif dimaksudkan proses membangun kembali pola pikir hakim dalam menangani suatu perkara (korupsi) yang didasarkan pada asumsi-asumsi, konsep-konsep dan prinsip-prinsip hukum progresif dalam rangka mewujudkan nilai-nilai hukum dalam memutuskan perkara. ${ }^{26}$

Nilai-nilai hukum itu tersimpan dan juga tersimbolkan dalam judul (irah-irah) di setiap putusan hakim yaitu: "demi keadilan berdasarkan ketuhanan yang maha esa". Judul (irah-irah) tersebut harus dicantumkan di setiap putusan hakim dan jika tidak dicantumkan berdasarkan Pasal 197 ayat (1) Undang-Undang Nomor 8 Tahun 1981 tentang Kitab Undang-Undang Hukum Acara Pidana (selanjutnya disebut KUHAP) yaitu putusan batal demi hukum. Sementara itu dalam Pasal 2 ayat (1) Undang-Undang Nomor 48 Tahun 2009 tentang Kekuasaan Kehakiman yang mengatur: peradilan dilakukan "Demi Keadilan Berdasarkan Ketuhanan Yang Maha Esa". Selanjutnya dalam Pasal 8 ayat (3) Undang-Undang Nomor 16 Tahun 2004 tentang Kejaksaan mengatur: Demi keadilan dan kebenaran berdasarkan Ketuhanan Yang Maha Esa, jaksa melakukan penuntutan dengan keyakinan berdasarkan alat bukti yang sah.

Pentingnya suatu konstruksi baru pola pikir hakim bertolak dari kondisi existing (hasil studi) atas penanganan perkara (korupsi) oleh hakim di pengadilan saat ini banyak mengalami kemerosotan atau dapat dibilang kegagalan untuk menghadirkan hukum yang adil, bermanfaat dan melindungi kepentingan masyarakat (social justice). Pola pikir hakim yang bercorak positivistik perlu dibangun kembali (ditata ulang) berdasarkan pola pikir baru yang progresif dalam

25 Ibid, h. 8.

26 Radbruch yaitu niali keadilan, kepastian, dan kegunaan. Gustav Radbruch. (2011). The Legal Philosophies of Lask, Radbruch, and Dabin. Cambridge: Massachusetts, Harvard University Press, h.107-108. Bandingkan dengan tulisan Ridwan. (2011). Memunculkan Karakter Hukum Progresif dari Asas-asas Umum Pemerintahan yang Baik Solusi Pencarian dan penemuan Keadilan Substantif. Jurnal Hukum Pro Justitia, Vol.27, No.1, h. 67- 80. 
menyelesaikan problem hukum yang muncul akhir-akhir ini yang semakin kompleks dan rumit, terutama dalam memecahkan masalah korupsi.

Dari uraian di atas dapat ditemukan tujuan dan semangat yang sama antara hukum progresif dengan interessenjurisprudenz, setidak-tidaknya dalam lima hal, yaitu pertama, semangat menempatkan kepentingan dan kebutuhan manusia/rakyat sebagai tujuan utama dari hukum; kedua, kehendak menyelenggarakan hukum secara kreatif; ketiga, pentingnya kepekaan, empati, serta dedikasi dalam pe- nyelenggaraan/penegakan hukum; keempat, kearifan manusia (aparat penegak hukum) menjadi kata kunci pencapaian keadilan; dan kelima, tidak anti peraturan, akan tetapi berusaha terus-menerus memberi makna baru dalam ruang dan waktu yang tepat. ${ }^{27}$

Dalam menangani suatu perkara, hakim tidak dapat lepas dari pilihan nilai-nilai. Hakim akan memilih nilai-nilai yang dianggap penting berdasarkan pemaknaanya atas nilai-nilai tersebut. Dalam praktik, pilihan atas nilai-nilai itu sangat dipengaruhi oleh tingkat kepentingan, kebutuhan hidup, lingkungan dan kebiasan serta karakter pribadi hakim. Dalam praktik kadang terjadi pergeseran pilihan nilainilai oleh hakim yakni dari nilai-nilai ideal atau objektif hukum ke nilai-nilai pragmatik atau subjektif yang dipentingkan dan diutamakan oleh hakim dalam penanganan perkara tertentu. Artinya penanganan suatu perkara dapat menjadisumber komoditi untuk mendapatkan keuntungan pribadi, baik politik maupun ekonomi.

c. Upaya untuk Memutus Perkara yang Bebas Tendensi

Hakim memikul tanggung jawab yang sangat berat ketika memutus perkara. Putusan yang dijatuhkan hakim tidak hanya dipertanggung-jawabkan kepada para pihak namun juga di hadapan sang khalik. Keberadaan irah-irah "demi keadilan berdasarkan ketuhanan yang maha esa" dalam setiap putusan bukanlah sekedar formalitas bentuk belaka, namun mengandung maksud yang begitu dalam agar putusan hakim harus benar-benar mengandung keadilan yang berdasarkan pada nilai-nilai ketuhanan.

Demi memperoleh putusan yang berkeadilan diperlukan sikap hakim dalam memeriksa dan memutus perkara terbebas dari tendensi atau kecenderungan berpihak kepada salah satu pihak. Pihak yang berkedudukan sebagai penggugat maupun tergugat dalam ranah perdata dan pihak yang berkedudukan sebagai jaksa penuntut dan terdakwa beserta pembelanya harus diperlakukan sama dalam pemeriksaan perkara di persidangan. Hakim harus bersikap tidak berpihak dan memandang sama para pihak, tidak membeda-bedakan orang. Keunggulan dalam ranah sosial karena memiliki jabatan, harta kekayaan, keturunan, bentuk fisik, dan sebagainya tidak berlaku bagi hakim dalam memeriksa dan memutus suatu perkara, baik pidana maupun perdata karena semua orang adalah dipandang sama di hadapan hukum (equality before the law). 


\section{Kesimpulan}

Faktor-faktor yang menjadi pertimbangan hakim pada kasus tindak pidana korupsi sehingga menimbulkan disparitas putusan pidana meliputi (1) faktor perundangundangan; (2) faktor pribadi hakim, seperti misalnya agama, pendidikan, nilai yang dianut dan moralitas serta mentalitas hakim; dan (3) faktor lingkungan yang mencakup faktor politik dan ekonomi.

Konsep ideal agar tidak ada lagi disparitas pidana pada penjatuhan pidana tindak pidana korupsi dapat dilakukan dengan cara (1) dibuatnya pedoman pemidanaan yang dapat dijadikan acuan atau rambu-rambu bagi hakim untuk menjatuhkan sanksi pidana; (2) mengkonstruksi kembali (rekonstruksi) pola pemikiran dan perilaku etik hakim berbasis hukum progresif agar dapat menghadirkan hukum yang adil; dan (3) upaya untuk memutus perkara yang bebas tendensi dan hakim harus bersikap tidak berpihak dan memandang sama para pihak, tidak membeda-bedakan orang, demi memperoleh putusan yang berkeadilan.

\section{Daftar Pustaka}

\section{$\underline{\text { Buku }}$}

Argama, Rizky. (2014). Pembukaan Pedoman Perilaku Hakim yang Disusun Pada Tahun 2013 oleh Mahkamah Agung Republik Indonesia. Jakarta: Fakultas Hukum UI.

Arief, Barda Nawawi. (2011). Pembaharuan Hukum Pidana dalam Perspektif Kajian Perbandingan. Bandung: Citra Aditya Bakti.

Diantha, I Made Pasek. (2017). Metodologi Penelitian Hukum Normatif dalam Justifikasi Teori Hukum. Jakarta: Prenada Media Group.

Ibrahim, Johny. (2012). Teori dan Metodologi Penelitian Hukum Normatif. Malang: Banyumedia.

Irianto, Sulistyowati dan Shidarta. (2012). Metode Penelitian Hukum Konstelasi dan Refleksi. Jakarta: Yayasan Obor Indonesia.

Litbang Mahkamah Agung. (2011). Kedudukan dan Relevansi Yurisprudensi untuk Mengurangi Disparitas Putusan Pengadilan. Jakarta: Puslitbang Hukum dan Peradilan Mahkamah Agung RI.

Loqman, Loebby. (2012). HAM dalam HAP. Jakarta: Datacom.

Mangkusubroto, Kuntoro. (2013). Pemberantasan Mafia Hukum. Jakarta: UNDP.

Manson, Allan. (2014). The Law of Sentencing, New York: Irwin Law.

Marzuki, Peter Mahmud. (2011). Penelitian Hukum. Jakarta: Kencana Prenida Media.

Menski, Werner. (2013). Comparative Law in a Global Context, The Legal Systems of Asia and Africa. Second Edition. New York: Cambridge University Press.

Muladi dan Barda Nawawi Arief. (2012). Dampak Disparitas Pidana dan Usaha Untuk Mengatasinya. Bandung: Alumra.

Muladi. (2011). Independensi Kekuasaan Kehakiman. Semarang: Penerbit Undip.

Radbruch, Gustav. (2011). The Legal Philosophies of Lask, Radbruch, and Dabin. Cambridge: Massachusetts, Harvard University Press.

Sudarto. (2006). Kapita Selekta Hukum Pidana. Bandung: Alumni.

Suseno, Franz Magnis. (2013). Etika Politik: Prinsip-Prinsip Moral Dasar Kenegaraan Modern. Jakarta: Gramedia Pustaka Utama.

Syamsudin, M. (2012). Konstruksi Baru Budaya Hukum Hakim Berbasis Hukum Progresif. Jakarta: Kencana Prenada Media Group. 
Warassih, Esmi. (2013). Pemberdayaan Masyarakat dalam Mewujudkan Tujuan Hukum (Proses Penegakan Hukum dan Keadilan). Semarang: Pustaka Undip.

\section{Jurnal}

Nursiti, N., \& Fakhrullah, F. (2015). Disparitas Penjatuhan Pidana Kurungan Pengganti Pidana Denda dalam Putusan Kasus Narkotika. Kanun: Jurnal Ilmu Hukum, 17(2), 303-325.

Prakoso, Denny Agung. (2015). Disparitas dalam Penjatuhan Pidana pada Perkara Korupsi Menurut Undang-Undang Nomor 20 Tahun 2001 tentang Korupsi. Jurnal Hukum dan Advokasi, 2(3).

Ridwan, R. (2009). Memunculkan Karakter Hukum Progresif Dari Asas Asas Umum Pemerintahan Yang Baik Solusi Pencarian dan Penemuan Keadilan Substantif. Jurnal Hukum Pro Justitia, 27(1).

Suhardin, Yohanes. (2018). Paradigma Rule Breaking dalam Penegakan Hukum yang Berkeadilan. Jurnal Hukum Pro Justitia, 26(3).

Syamsudin, M. (2011). Rekonstruksi pola pikir hakim dalam memutuskan perkara korupsi berbasis hukum progresif. Jurnal Dinamika Hukum, 11(1), 11-21.

Wisnubroto, A. (2013). Upaya Mengembalikan Kemandirian Hakim Melalui Pemahaman Realitas Sosialnya. Jurnal Hukum Pro Justitia, 20(1).

\section{Peraturan Perundang-Undangan}

Kitab Undang-Undang Hukum Pidana.

Undang-Undang Nomor 8 Tahun 1981 tentang Kitab Undang-Undang Hukum Acara Pidana.

Undang-Undang Nomor 3 Tahun 1971 tentang Pemberantasan Tindak Pidana Korupsi. Undang-Undang Nomor 31 Tahun 1999 tentang Pemberantasan Tindak Pidana Korupsi.

Undang-Undang Nomor 14 Tahun 1970 tentang Ketentuan-Ketentuan Pokok Kekuasaan Kehakiman.

Undang-Undang Nomor 16 Tahun 2004 tentang Kejaksaan.

Undang-Undang Nomor 48 Tahun 2009 tentang Kekuasaan Kehakiman. 